\title{
Prevalence of asthma in a Portuguese countryside town: repercussions on absenteeism and self-concept
}

\author{
L.M. Borrego, M. César, P. Leiria-Pinto and J.E. Rosado-Pinto \\ Immunoallergy Department. Dona Estefânia Hospital. Lisbon. Portugal.
}

\begin{abstract}
Background: Childhood asthma represents an increasing health problem and is the leading cause of hospital admission and absenteeism in children with chronic disease. It also compromises quality of life, eventually contributing to disturbances in self-concept. Self-concept is a recent and global perspective of "the self" and relates to skills, self-image and self-esteem. Little information is available on this topic and there are no data from Portuguese countryside towns.
\end{abstract}

Objective: The aim of this study was to determine the prevalence of asthma among all school children in the 5th and 6th grades in a Portuguese countryside town and to establish its possible correlation with absenteeism and self-concept.

Methods: In April 2002, two questionnaires were administered in the presence of the researcher to a group of 950 children attending different schools. The children completed the internationally renowned questionnaires: ISAAC and the Self-Concept Scale by Susan Harter.

Results: Our sample $(n=818)$ had a mean age of 11 years (10-15 years) and a male-to-female ratio of $1 / 1$. The cumulative prevalence of asthma was

Correspondence:

L.M. Borrego, MD.

Serviço de Imunoalergologia

Hospital Dona Estefânia

Rua Jacinta Marto

1169-045 Lisboa. Portugal

E-mail: luis.borrego@netcabo.pt
$11.9 \%$ and that of active asthma was $8.8 \% ; 63.9 \%$ of asthmatics were male and $36.1 \%$ were female. The mean age of asthmatics was 11.34 years and $74 \%$ had active symptoms. Comparison of this group of 97 asthmatic children with the remaining children revealed a statistically significant correlation between the presence of asthma and school absenteeism (global: $p=0.04$; gymnastics: 0.05). Regarding the Self-Concept Scale a statistically significant association was found between the presence of asthma and school achievement $(p=0.027)$, physical appearance $(p=0.015)$, behavior $(p<0.000)$ and self-esteem $(p<0.000)$. No statistically significant correlations were found in social acceptance $(p=0.289)$ or athletic competence $(p=0.085)$. Asthmatic boys had higher self-concept scores than girls, except in the domain of behavior.

Conclusions: Twelve percent of the population studied was asthmatic. In asthmatic children, absenteeism was higher and self-concept was lower for almost all domains, except social acceptance and athletic achievement, probably due to overprotection.

Key words: Childhood asthma. Self-concept. Impact asthma.

\section{RESUMEN}

Introducción: La asma infantil representa un creciente problema de salud, siendo la causa principal de visitas al hospital y de absentismo en los niños con enfermedades crónicas. También compromete la calidad de vida, contribuyendo al desarrollo de perturbaciones en el auto-concepto. El auto-concepto es una perspectiva reciente y global del "uno mismo" con relación a las capacidades, auto-imagen e auto-estima. Hay poca información con relación a 
este tema y en el caso de ciudades portuguesas de provincia todavia no existen datos.

Objetivo: el objetivo de este estudio fue estudiar la prevalencia del asma en niños del 5.., 6. año escolar, en una ciudad portuguesa de provincia, y estabelecer una posible correlación con el absentismo y autoconcepto.

Métodos: en el mes de Abril del 2002 se efectuaran dos encuestas a 950 niños de todas las escuelas oficiales y siempre con la presencia del investigador. Los niños respondieron a encuestas de renombre internacional: ISAAC; Self-Concept Scale de Susan Harter.

Resultados: La muestra de la encuesta $(n=818)$ presenta una media de edad de 11 años (10-15 años) y una relación $\mathrm{M} / \mathrm{F}$ de $1 / 1$. Prevalencia cumulada de asma: 11,9\%; Asma activa: 8,8\%;63,9\% asmáticos masculinos y $36,1 \%$ femeninos. Edad media de los asmáticos: 11,34 años; $74 \%$ con síntomas activos. Comparando este grupo de 97 niños con síntomas activos con los demás, se encontró correlación estadística significativa entre la presencia de asma y absentismo (global: $p=0,04$; Gimnástica: $p=0,05$ ). En relación a la escala de auto-concepto fue posible encontrar correlación estadística sinificativa entre la presencia del asma y el éxito escolar $(p=0,027)$, aspecto físico $(p=0,015)$, comportamiento $(p=0,000)$ y auto-estima $(p=0,000)$. No se detectó correlación estadística significativa con relación a la aceptación social $(p=0,289)$ y resultados deportivos $(p=0,085)$. Los niños asmáticos del sexo masculino presentan resultados más elevados de auto-concepto que el sexo femenino, con excepción del comportamiento.

Conclusiones: en la población estudiada $12 \%$ eran asmáticos. Los niños asmáticos presentan mas absentismo y un menor nivel de auto-concepto, con excepción de aceptación social y resultados deportivos, probablemente resultante de un exceso de protección.

Palabras clave: Asma en los adolescientes. Autoconcepto. Impacto de la asma.

\section{INTRODUCTION}

Bronchial asthma is a chronic disease with high prevalence during childhood, being the leading cause of hospital admission in children with chronic disease $e^{1-3}$.

It is a major cause of absenteeism with repercussions on quality of life, and a high socio-economic impact, for which it should be considered as a Public Health problem ${ }^{2,3}$.
In order to know the prevalence of allergic disease worldwide an international project involving more than 150 countries has been developed during the last ten years. This is the International Study of Asthma and Allergies in Childhood (ISAAC), which comprehends 3 different phases. Phase I was designed to know the prevalence and severity of asthma and other allergic diseases (rhinitis, eczema) worldwide, using questionnaires; Phase II was designed to study etiological factors, evaluating bronchial hypereactivity and atopy, and finally Phase III which was a repetition of Phase I in order to verify the evolution of those diseases regarding their prevalence ${ }^{4-6}$.

This multicentric study aimed to study the prevalence of allergic diseases in children of two different age groups: 6-7 and 13-14 years old, using questionnaires and videos (for the younger ones)

The higher prevalence was obtained in Great Britain, New Zealand and Australia, and the lower in China and Indonesia, with an intermediate position for Portugal (Phase III: Actual asthma- 12,9 \%: 6-7 yrs old/ 21,8\%: 13-14 yrs old) $)^{5-8}$.

Castelo Branco is a portuguese countryside town with 70.000 inhabitants and 7,7 newborn/1000 inhabitants. There are no studies about the prevalence of asthma in these region of Portugal.

School absenteeism has been commonly used as a marker to evaluate the social repercussions due to asthma, with a large number of studies proving to be higher among asthmatics comparing to healthy children ${ }^{1,7,9}$.

Chronic diseases may affect self-esteem and cause familiar conflicts ${ }^{10}$. It is accepted the association between severe asthma and anxiety, depression and lower self-esteem ${ }^{11}$.

Their families tend to adopt an attitude that limits the child physical activity and overprotection rising in their children feelings of anger and denial of the disease $^{12}$.

Asthma has implications on children's life in several domains such as physical, psychological and social areas, disturbing their development and the construction of their personality and self-concept ${ }^{12,13}$.

The evaluation of Self-concept has been proposed as an important tool to achieve a global impression of a subject's personality ${ }^{12-14}$.

There are several scales and models to evaluate it, underlying different models and conceptions of Self-Concept, which can be divided in unidimensional and multidimensional ${ }^{15-18}$.

The unidimensional models define Self-Concept as the sum of several specific competences regardless the analysed competence (Coopersmith Self-Esteem Inventory or Piers-Harris Self-Concept Scale) while the multidimensional ones consider the exis- 
tence of interrelation and hierarquization between specific domains ${ }^{19,20}$.

The authors used the Self-Concept Scale of Susan Harter based on a multidimensional model, in which there are five specific domains that contribute to Self-Concept and an independent and superior domain: Self-esteem. This scale is adapted for children in school age $\mathrm{e}^{22-24}$.

The five specific domains are: School competence, Athletic Competence, Social Acceptance, Physical Appearance and Behaviour, interdependent between them ${ }^{24}$.

It is assumed that although a child might have a low perceived competence in one specific domain it might not interfere with the global self-esteem because it might be a domain not considered important to the child ${ }^{24}$.

Among the specific domains, School Competence is highly related to Behaviour and the remaining domains are highly related between them ${ }^{24}$.

Physical appearance is the specific domain most related with Self-Steem in opposition to Athletic Competence, even in specific groups such as athletes or brillant students, being present after 4 years old, particularly in girls ${ }^{24}$.

It is very important to evaluate Self-Concept in children with chronic diseases to perceive lower competences in specific domains and establish individual programs to improve them and make possible a healthy construction of personality as well as integration with their peers.

The purpose of this study was to calculate the prevalence of asthma in a Portuguese countryside town among all children of the $5^{\text {th }}-6^{\text {th }}$ grade in school and to establish the possible correlation of its presence on absenteeism and self-concept.

\section{MATERIAL AND METHODS}

Our study population included 950 children whose ages ranged from 10 to 15 years old, in a countryside town in Portugal: Castelo Branco. This population corresponds to all students at $5^{\text {th }}$ and $6^{\text {th }}$ grades in the city.

Informed consent has been obtained from parents of all children participating in this study, after authorization of the four participating schools.

The researchers have been present during all days of research.

We used the portuguese version of International Study of Asthma and Allergies in Childhood's (ISAAC) questionnaire to know the prevalence of asthma, using the specific page of questions regarding asthma evaluation, in a total of 8 questions, comprehending questions to know the prevalence as well as the severity of the disease. Each question has two options for answer: Yes/No, with exception of those referring to severity of the disease ${ }^{5,6}$.

The Susan Harter's Self-Concept Scale has been used to evaluate Self-Concept. This is a scale composed by 36 questions, with 6 questions for each specific domain (School Competence, Athletic Competence, Social Acceptance, Physical Appearance and Behaviour) and 6 questions to evaluate Self-esteem. Each question has four options for answer. The child has to decide, between two statements presented for each question, in which statement recognises more similarities to herself, and after that to decide if that similarity is total or partial. To each domain, 3 questions start with positive questions referring to high-perceived competence and the remaining three the other way around. The questions for each domain are distributed along the questionnaire. There is a final score for each domain, obtained after making the sum of scores in all 6 questions for each domain. The questions starting with positive statements are classified with 4-3-2-1 points, sequentially and the negative questions, the opposite way ${ }^{24}$.

The researcher spent two days at each school. The questionnaires have been distributed collectively in each classroom. All children had 5 minutes for the ISACC questionnaire and 20 minutes for the scale of Susan Harter. The researcher briefly explained the procedures to answer to both questionnaires, before distributing them. He has been present in every classroom during the study.

The information regarding absenteeism has been recruited by analysing school records. Demographic data (age, sex) were written on the questionnaires sheets. Each child had a code number. All information and questionnaires were anonymous.

The statistical analysis was performed by SPSS/PC (Version 10-2000), SPSS, Inc., USA. Pearson's correlation was used for the association of intervalar data, chi-square test to analyse the association of categoric data, and the nonparametric Kruskall-Wallis test for the association of categoric and continuous data. Statistical significance was accepted at $p \leq 0,05$.

The present study was done during 2002, namely the data collection in April (field research) and the following analysis from May till November.

\section{RESULTS}

\section{Prevalence of Asthma}

We evaluated 818 children (399 girls, 419 boys) from the initial population (950), corresponding to 
Table I

Children's distribution according to prevalence of asthma and sex

\begin{tabular}{|c|c|c|c|c|c|c|}
\hline & \multicolumn{2}{|c|}{ Yes } & \multicolumn{2}{|c|}{ No } & \multicolumn{2}{|c|}{ Total } \\
\hline & N. & $(\%)$ & N. & $(\%)$ & N. & $(\%)$ \\
\hline Girls & 35 & 4.28 & 364 & 44.50 & 399 & 48.78 \\
\hline Boys & 62 & 7.58 & 357 & 43.64 & 419 & 51.22 \\
\hline Total & 97 & 11.86 & 721 & 88.14 & 818 & 100,00 \\
\hline
\end{tabular}

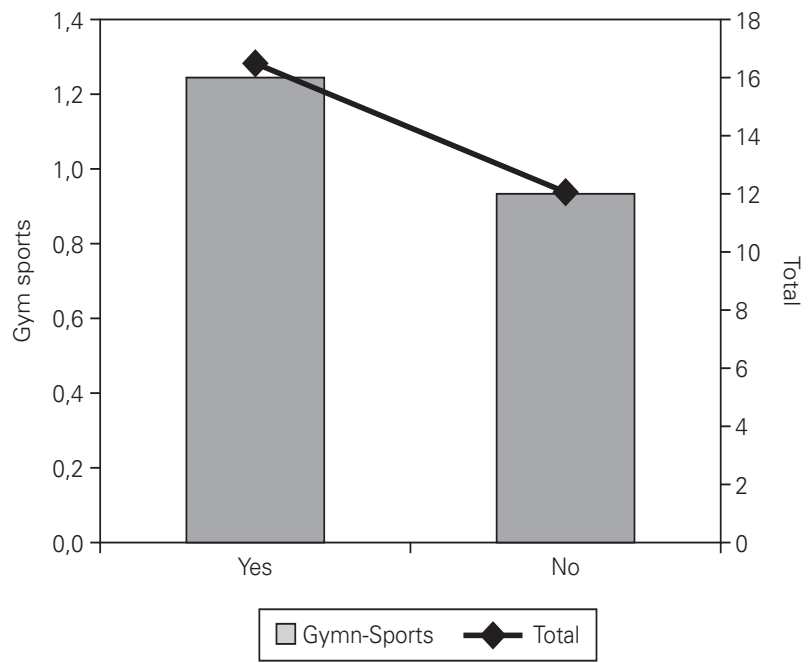

Figure 1.-Absenteeism distribution according to the presence of asthma in all disciplines and in Gymnastic and sports. Kruskal-Wallis, $p=0.05$ (Gym-Sports) e 0.04 (Total).

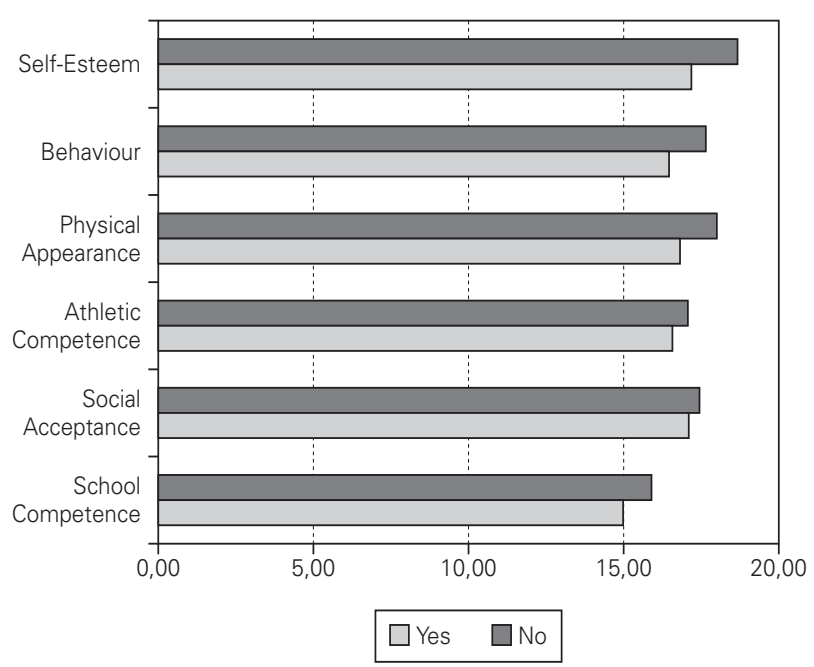

Figure 2.-Self-Concept scores using Susan Harter scale according to the presence of asthma.
Table II

Self Concept's domains differences between asthmatic and healthy children

\begin{tabular}{|c|c|c|c|c|c|c|}
\hline & $\begin{array}{c}\text { School } \\
\text { Compet. }\end{array}$ & $\begin{array}{l}\text { Social } \\
\text { Accept. }\end{array}$ & $\begin{array}{l}\text { Athletic } \\
\text { Compet. }\end{array}$ & $\begin{array}{l}\text { Physical } \\
\text { Appear. }\end{array}$ & Behaviour & Self-esteem \\
\hline Chi-Squarea & 4.883 & 1.126 & 2.964 & 5.956 & 13.545 & 16.109 \\
\hline df & 1 & 1 & 1 & 1 & 1 & 1 \\
\hline$p$ & 0.027 & 0.289 & 0.085 & 0.015 & $<0.001$ & $<0.001$ \\
\hline
\end{tabular}

$86,1 \%$ of participation in the study. The mean age was 11 years old (10-15 years) and a M/F ratio of 1/1.

The prevalence of cumulative asthma was $11,86 \%$ (table I), with a higher prevalence in male, with a statistical difference between sex (Kruskall Wallis: $p=0,008$.

Among asthmatic children the median age was 11,34 years old (SD: 1,26). The majority of them (74\%) had symptoms during the last 12 months, being the prevalence of current asthma $8,8 \%$. Regarding the severity of asthma, $74 \%$ of children with current asthma had 1 to 3 attacks during the last year and $30 \%$ had nocturnal symptoms (including cough).

\section{Absenteeism}

Asthmatic children had a higher absenteeism ( 5 days in average), statistically significant for all disciplines $(p=0.05)$ and for Gymnastic and Sports $(p=0.04)$, comparing to the remaining population (fig. 1), with girls having higher absenteeism than boys.

\section{Self-Concept}

Regarding the analysis of Self-Concept, asthmatic children had lower scores in all specific domains (School Competence, Athletic Competence, Social Acceptance, Physical Appearance and Behaviour) as well as in Self-esteem, comparing to healthy ones, with the higher difference between them at Self-esteem and the lowest difference at Social Acceptance (fig. 2).

The lower scores in asthmatic children were statistically significant in School Competence, Physical Appearance, Behaviour and Self-esteem (table II).

Among asthmatic children, as well as in total population, boys had higher scores than girls in all domains of Self-Concept with exception of Behaviour. Those differences had maximum expression on 
Physical Appearance scores (fig. 3), and were statistically significant $(p=0,04)$.

There were no statistically significant differences on Self-Concept domains between children with and without current asthma $(0,08 \leq p \leq 0,96)$.

\section{DISCUSSION}

The cumulative prevalence of asthma was $11,9 \%$, being $8,8 \%$ the prevalence of current asthma, enhancing this disease as one of the most frequent chronic diseases in children. To calculate the prevalence of asthma, we used the ISAAC questionnaire. This instrument is commonly used internationally, allowing the comparison of different populations in different countries.As expected, the obtained data are lower than data from New Zealand, England or Australia, and higher than the ones from China or Indonesia, ${ }^{5,6}$.

The response rate was $86,1 \%$. It can be considered a reliable rate comparing to the commonly $80 \%$ achieved in a large number of countries participating in the ISAAC project ${ }^{5,6}$.

Although the previous data were supported by a previous study made in Portugal by Rosado Pinto et al (1996), in several portuguese cities (Lisbon, Coimbra, Porto, Portimão, Funchal) using the same methodology in children between 13-14 years old ${ }^{25,26}$. These authors stress the raise of prevalence of asthma in Portugal during the last years, as previously quoted, which lead us to consider the disease as a major public health problem.

More updated results regarding the ISAAC project phase III (2002), report higher levels for cumulative asthma $(21,8 \%)$ as well as for current asthma $(11,8 \%)$, among children with 13 to 14 years old, in Portugal27.

In the referred age group, the obtained data are lower than the national average (cumulative: $21,8 \%$; current: $11,8 \%$ ), as well as lower than data obtained from different Portuguese cities by the seaside, such as Lisbon (current: 14,6 \%), Portimão (cumulative: 18,2 \%; current: 9,7\%), Porto (cumulative: $22,1 \%$; current: 13,1\%), Madeira (cumulative: 19,3\%; current: $9,0 \%$ ) or in the countryside such as Évora (cumulative: $19,8 \%$; current: $12,8 \%)^{27}$.

In all studies there was a higher prevalence of asthma in boys, similarly to what we obtained in this study.

The majority of children (74\%) had mild asthma (1-3 attacks), as it is commonly accepted in international studies and in accordance to published data by Mario Morais Almeida et al, in ISAAC study phase II in Lisbon (70\%). Regarding nocturnal symptoms, including cough, the obtained data (30\%) are similar to

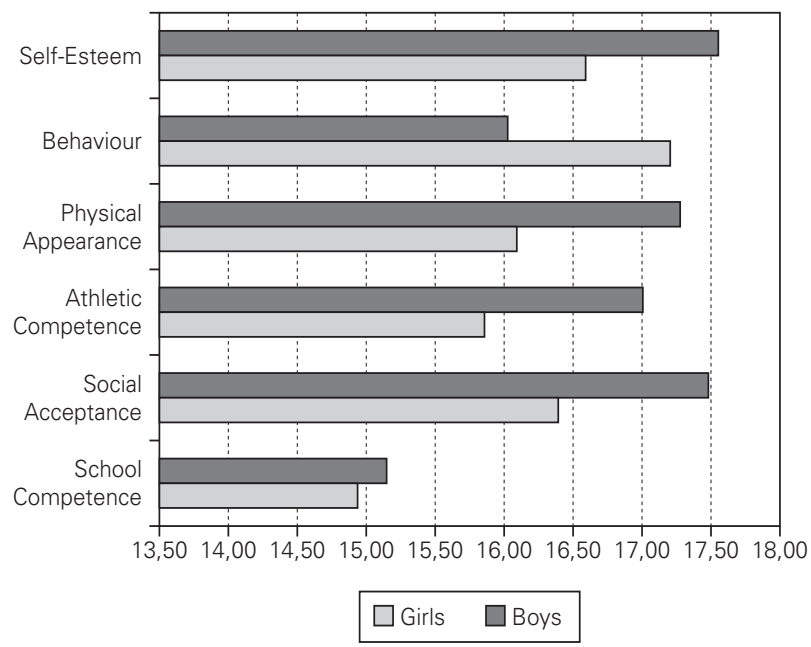

Figure 3.-Self-Concept scores using Susan Harter's scale, according to sex, in asthmatic children.

the ones obtained in ISAAC study phase III in all cities mentioned earlier ${ }^{27}$.

In our study, asthmatic children had higher absenteeism than their peers, in average 5 days, namely in boys. This differrence was statistically significant.

The obtained results are supported by some studies but not by other ones. In fact, in 1998 a study made in United States of America including 7465 children, from 10 to 17 years old, concluded that asthmatic children had in average 4,6 days of absenteeism per year due to their disease. This was higher than the absenteeism of healthy children ${ }^{12}$.

By contrast, a study made in Scotland in 10868 children from 1-15 years old, found no differences among asthmatic children compared to healthy ones, despite using a similar metodology of the study mentioned above ${ }^{9}$.

During 1998 a study made by Leiria Pinto et al in a Portuguese countryside town - Lourinhã, concluded that among 1879 children, half of the asthmatic ones had in average 6 absent days per year ${ }^{28}$.

According to Professor Bousquet at ARIA (Impact of Allergic Rhinitis on Asthma) the majority of patients with asthmahave rhinitis, which in conjunction may conduce to impairment of quality of life and higher absenteeism year ${ }^{29}$.

Paul Cawenberg, also estabilishes the relation between asthma and allergic rhinitis, and their relation to impairment of quality of life and absenteeism ${ }^{30}$.

There are no studies in Portugal regarding the relation asthma-self-concept, using the multidimensional model of Susan Harter, which gives a unique characteristic to the present study.

The obtained data, with lower scores for asthmatic children than healthy ones, are in accordance to 
published studies ${ }^{31-35}$, particularly in Physical Appearance $^{36}$. Nevertheless, other studies found no differences between groups ${ }^{37}$.

Among healthy children Physical Appearance is the specific domain with higher scores revealing the importance attributed to this domain during adolescence. It is well know the importance of appearance in modern societies, particularly for teenagers, once the acceptance inside a group among peers depend on it.

Asthmatic children tend to be less developed achieving puberty later than healthy ones ${ }^{38,39}$, which has tremendous implications on their physical perception and self-esteem, domains traditionally connected in all children since 4 years old, even in special groups such as athletes, as mentioned previously, explaining the lower scores obtained and the biggest difference between them in this domain ${ }^{24}$.

Regarding the lower scores obtained for School Competence, the authors enhance the presence of mild asthma, usually neglected by children and respective parents regarding the need for treatment, as well as the nocturnal symptoms, which, in combination may lead to attention disorders, particularly during morning compromising the intellectual skills. Moreover the higher absenteeism compromises the educational commitment ${ }^{40}$.

As mentioned before, Paul Cawenberg states that the majority of asthmatic children have rhinitis, being the former responsible for sleep disturbances and daytime fatigue, leading to intellectual and attention impairment ${ }^{30}$, which may compromise the learning process.

Another possible explanation was the tendency for asthmatic children to be more demanding with themselves regarding intellectual skills once they have physical limitations in the presence of uncontrolled asthma.

The classical association of School Competence and Behaviour, as well as for the possible tendency to anger and denial facing an uncontrolled disease with feelings of inferiority, disability and stress may lead to lower Behaviour scores ${ }^{24}$.

There were no statistical differences regarding Athletic Competence and Social Acceptance, domains usually linked, according to Susan Harter ${ }^{24}$.

Asthmatic children's families and teachers usually spare them to do physical exercise leading to the common neglect of the importance of physical skills, explaining way this specific domain isn't valorised by them. They assume that they shouldn't be compared with healthy children regarding athletic skills and therefore any skill achieved is best valorised. Another possible explanation is that asthmatic children are usually encouraged to swim since infancy achieving high scores in this sport during Gym classes $31,34,36,41$.
As expected, boys have higher scores in all specific domains as well as in Self-esteem, except in Behaviour. It is not surprisingly at all, once boys usually have worse behaviour than girls, and it is usually expected to be so $^{24,34,41}$.

The higher differences among sex are seen at Athletic Competence, but among asthmatic children are at Physical Appearance. The authors couldn't find any explanation for this fact in the literature.

Children with current asthma had no differences regarding to Self-Concept scores, comparing to the remaining asthmatics, which can be explained by the fact that the construction of self-concept takes several years, as it is a long process, not being so much affected by recent events.

A positive self-concept is essential for personal happiness, adaptation among peers and success ${ }^{42}$. Children with lower self-concept, often express anxiety and relation problems ${ }^{35}$.

The knowledge of the association between personal success and self-concept as well as the effect of chronic disease on it, stress the responsibility of all health and education professionals for the need of evaluation of self-concept in children with chronic diseases in order to improve it.

\section{CONCLUSIONS}

Asthma is one of the most frequent chronic diseases in childhood and adolescence, with a high impact on absenteeism and self-concept, namely in the construction of personality. It has implications on biological, psychological and social maturation of the adolescence.

It is very important to establish intervention school programs in order to develop an in depth knowledge about asthma implications and emphasise the equality of asthmatic children comparing to healthy children, in all domains, as long as the disease is well controlled.

These programmes should include doctors, psychologists, teachers, parents, asthmatic students and their peers.

The authors stress the importance of a good understanding of the disease to allow for the real inclusion of the asthmatic children in school and society.

\section{REFERENCES}

1. Global strategy for asthma management and prevention. NHLBIMHO Workshop Report. Bethesda: National Institutes of Health, National Heart, Lung and Blood Institute, publication n. 02-3659; 2002. 
2. Michel BF, Neukirch F, Bousquet J. Asthme: um probléme mondiale de Santé Públique. Bull Acad Natle Méd. 1995;179: 279-97.

3. Forero R, Bauman A, Young L, Larkin P. Asthma prevalence and management in Australian adolescents: results from three community surveys. J Adolesc Health. 1992;13:707-12.

4. Samet JM. Epidemiological approaches for the identification of asthma. Chest. 1987;91:74-8.

5. Asher MI, Keil U, Anderson HR, Beasley R, Crane J, Martinez $\mathrm{F}$, et al. International study of asthma and allergies in childhood (ISAAC): rationale and methods. Eur Respir J. 1995;8:483-91.

6. The International Study of asthma and Allergies in Childhood (ISAAC) Steering Committee. Worldwide variations in the prevalence of symptoms os asthma, allergic rhinoconjunctivitis and atopic eczema: ISAAC. Eur Respir J. 1998;12:315-35.

7. Robertson CF, Heycoch E, Bishop J, Nolan T, Olinsky A, Phelan PD. Prevalence of asthma in Melbourne schoolchildren: changes over 26 years. BMJ. 1991. p. 302.

8. Peat JK, van den Berg RH, Green WF, Mellis CM, Leeder SR, Woolcock AJ. Changing prevalence of asthma in Australian children. BMJ. 1994;308:1591-96.

9. McCowan C, Bryce FP, Neville RG, Crombie IK, Clark RA. School Absence - A valid morbidity marker for asthma? Health Bulletin. 1996;54:307-13.

10. Nocon A. Social and emotional impact of childhood asthma. Arch Dis Child. 1991;66:458-60.

11. Silverglade L, Tosi DJ, Wise PS, D'Costa A. Irrational beliefs and emotionality in adolescents with and without bronchial asthma. J Gen Psychol. 1994;121:199-207.

12. Newacheck, PW, McManus MA, Fox HB. Prevalence and Impact of Chronic Ilness Among adolescents. AJDC. 1991;145: 1367-73.

13. Fowler MG, Davenpor, MG, Garg R. School Functioning of US Children with asthma. Pediatrics. 1992:90:939-44.

14. Gibson PG, Henry RL, Vimpani HJ. Asthma knowledge, attitudes and quality of life in adolescents. Arch Dis Child. 1995; 73:321-6.

15. James W. Principles of psychology, Chicago: Encyclopedia Britannica; 1890

16. James W. Psychology: The briefer course, New York: Henry Holt; 1892.

17. Mead GH. Mind, self, and society from the standpoint of a social behaviorist, Chicago: University of Chicago Press; 1934.

18. Baldwin JM. Social and ethical interpretations in mental development: A study in social psychology, New York: Macmillan; 1897

19. Dweck CS. Self-theories and goals: Their role in motivation, personality and development. Nebraska Symposium on Motivation. Lincoln: University of Nebraska Press; 1991;38:199-235.

20. Oosterwegel A, Oppenheimer L. The self-system: Developmental changes between and within self-concepts, Hillsdale, NJ: Erlbaum; 1993.

21. Shavelson RJ, Hubner JJ, Stanton GC. Validation of construct interpretations. Review of Educational Research; 1976;46: 407-41.

22. Harter S. Issues in the assessment of the self-concept of children and adolescents. Through the eyes of the child: Obtaining self-reports from children and adolescents. Boston: Allyn e Bacon; 1990. p. 292-325.
23. Harter S. The perceived competence scale for children. Child Development. University of Chicago Press; 1982;53:87-97.

24. Alves-Martins M, Mata L, Monteiro V, Peixoto F. Escala de auto-conceito para crianças e pré-adolescentes de Susan Harter. Provas Psicológicas em Portugal. Braga: Apport; 1995. p. 79-89.

25. Rosado Pinto JE. Prevalence of rhinitis and asthma in Portuguese teenagers (ISAAC Study). Eur Resp J. 1996;9 Suppl. 23:233s.

26. Morais de Almeida M, Rosado Pinto J. Bronchial asthma in children: clinical and epidemiologic approach in different Portuguese speaking countries. Pediatr Pulmonol Suppl. 1999; 18:49-53.

27. Nunes C, Ladeira S, Rosado Pinto, J. Definição, Epidemiologia e Classificação da Asma na Criança. In: Rosado Pinto J, Morais de Almeida M, eds. A Criança Asmática no Mundo da Alergia. Lisboa: Euromédice; 2003; p. 35-55.

28. Leiria Pinto P, Cordeiro M, Pinto R. Allergol Immunopathol. 1999;27(5):245-53.

29. Bousquet J, Van Cauwenberge P, Khaltaev N. Allergic Rhinitis and its impact on asthma initiative (ARIA). ARIA Workshop Report - WHO. J Allegy Clin Immunol. 2001;108:S1-334.

30. Van Cauwenberge P, Bachert C, Passalacqua G, Bousquet J, Canonica GW, Durham SR, et al. Consensus statement on the treatment of allergic rhinitis. Allergy. 2000;55:116-34.

31. McNelis AM, Huster GA, Michel M, Hollingsworth J, Eigen $\mathrm{H}$. Factors associated with self-concept in children with asthma. J Child Adolesc Psychiatr Nurs. 2000;13:55-68.

32. Le Coq EM, Colland VT, Boeke AJ, Boeke P, Bezemer DP, van Eijk J. Reproducibility, construct validity, and responsiveness of the How are you? (HAY), a self-report quality of life questionnaire for children with asthma. J Asthma. 2000:37:43-58.

33. Padur JS, Rapoff MA, Houston BK, Barnard M, Danovsky M, Olson NY, et al. Psychosocial adjustment and the role of functional status for children with asthma. J Asthma. 1995;32: 345-53.

34. Routon JR, Sherrill C. Attitude toward physical education and self-concepts of asthmatic and nonasthmatic children taught by physical education specialists. Percept Mot Skills. 1989;68:1320-22.

35. Margalit M. Multivariate concept of psychosomatic illness the self-concept asthmatic children. Int J Soc Psychiatry. 1982; 28:145-8.

36. Brook U, Tepper I. Self image, coping and familial interaction among asthmatic children and adolescents in Israel. Patient Educ Couns. 1997;30:187-92.

37. Heilveil I, Schimel B. Self-esteem in asthmatic children. J Asthma. 1982;19:253-4.

38. Taylor WR, Newacheck PW. Impact of childhood asthma on health. Pediatrics. 1992;90:657-62.

39. Balfour-Lynn L. Growth and childhood asthma. Arch Dis Child. 1986;61:1409-55.

40. Speight ANP, Lee DA, Hey EN. Underdiagnosis and undertreatment of asthma in childhood. BMJ. 1983;286:1255-8.

41. Weston AR, Macfarlane DJ, Hopkins WG. Physical activity of asthmatic and nonasthmatic children. J Asthma. 1989;26:279-86

42. Burns R. Self-Concept Development and Education, London: Holt Education; 1982. 